\title{
Profitabilitas, Solvabilitas, Likuiditas, dan Nilai Perusahaan Rumah Sakit yang Terdaftar di BEI 2015-2019
}

\author{
Anry Umar ${ }^{1}$ \\ Fakultas Ekonomi dan Bisnis \\ Universitas Pelita Harapan, Indonesia \\ William Tjong ${ }^{2}$ \\ Fakultas Ekonomi dan Bisnis \\ Universitas Pelita Harapan, Indonesia
}

Surel : william.tjong@uph.edu

\section{ABSTRAK}

Rumah sakit merupakan perusahaan jasa yang bersifat sosioekonomi. Tujuan penelitian menganalisis pengaruh profitabilitas, solvabilitas, dan likuiditas terhadap nilai perusahaan industri rumah sakit. Populasi Penelitian adalah rumah sakit berada pada sektor 9 Trade, subsektor 96 health di BEI periode 2015-2019. Sampel yang diambil menggunakan metode nonprobability sampling dengan teknik purposif sampling sebanyak empat emiten. Penelitian ini menggunakan pendekatan kuantitatif dengan pengumpulan data kemudian diolah dengan Eviews dan teknik analisis yang digunakan adalah regresi data panel. Dari hasil peneltian dengan pendekatan FEM dan nilai signifikansi 0,05, didapatkan nilai p dari ROE 0.3403, DER 0.0000 dan CR 0.0076. Ketiganya memiliki koefisien regresi positif. Nilai intersep MIKA 3,37330659, SAME -3,121377, SILO 0,694458, dan SRAJ -1,303740. $\mathrm{R}^{2}$ ROE, DER dan CR terhadap PBV ialah $76,9 \%$. Kesimpulan penelitian, didapatkan DER dan CR berpengaruh signifikan dan berhubungan positif terhadap PBV. Sedangkan ROE tidak berpengaruh signifikan terhadap PBV dan berhubungan positif.

Kata Kunci: Nilai Perusahaan; Profitabilitas; Solvabilitas; Likuiditas; Rumah Sakit.

\section{Profitability, Solvency, Liquidity, and Company Value of Hospitals Listed on the IDX 2015-2019}

\footnotetext{
ABSTRACT

The hospital is a socio-economic service company. The research objective is to analyze the effect of profitability, solvency, and liquidity on the company value of the hospital industry. The study population was hospitals in sector 9 - trade, subsector 96 - health in the IDX for the 2015-2019. The sample was taken using nonprobability sampling method with purposive sampling technique of four issuers. This study uses a quantitative approach with data collection then processed with Eviews and the analysis technique used is panel data regression. From the results of the study using data panel regression with FEM approach and a significance value of 0.05; The p-value of ROE 0.3403, DER $0.0000 \mathrm{CR}$ 0.0076. ROE, DER and $C R$ have positive regression coefficients. The MIKA intercept value is 3.37330659, SAME 3.1121377, SILO 0.694458, and SRAJ -1.303740. $R^{2}$ of ROE, DER and $C R$ on $P B V$ is $76.9 \%$. The conclusion in this study, DER and CR have a significant and positive effect on PBV. Meanwhile, ROE has no significant effect on $P B V$, but has a positive relationship.
}

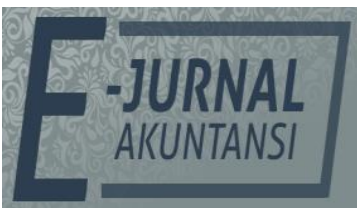

e-ISSN 2302-8556

Vol. 31 No. 5

Denpasar, Mei 2021

Hal. 1303-1317

DOI:

10.24843/EJA.2021.v31.i05.p17

PENGUTIPAN:

Umar, A., \& Tjong, W.

(2021). Profitabilitas,

Solvabilitas, Likuiditas, dan

Nilai Perusahaan Rumah

Sakit yang Terdaftar di BEI

2015-2019. E-Jurnal

Akuntansi, 31(5), 1303-1317

RIWAYAT ARTIKEL:

Artikel Masuk:

18 Maret 2021

Artikel Diterima:

24 Mei 2021

Keywords: The value of the company; Profitability; Solvency; Liquidity; Hospital.

Artikel dapat diakses : https://ojs.unud.ac.id/index.php/Akuntansi/index 


\section{PENDAHULUAN}

Era pandemi corona menjadi tantangan yang sangat berat untuk seluruh sektor usaha termasuk industri rumah sakit. Penyakit ini menginfeksi keseluruh negara tidak terkecuali negara Indonesia. Dari artikel IDN (2020) dikatakan profitabilitas industri rumah sakit tahun 2020 menurun dibandingkan tahun sebelumnya, sehingga rumah sakit harus menekan sales dari produk dan jasa pelayanan kesehatan. Pada data pertumbuhan Produk Domestik Bruto (PDB) triwulan II tahun 2020 yang dikeluarkan Badan Pusat Statistik, terlihat sektor kesehatan mengalami penurunan 4,15\% dari kuatral sebelumnya (IDN, 2020).

Hanya satu industri pengelolaan rumah sakit yang performanya di atas kinerja Indeks Perdagangan dan IHSG, industri yang dimaksud adalah PT Mitra Keluarga Karyasehat Tbk (MIKA). Analisis Pasar Modal menilai emiten kesehatan akan mengalami peningkatan pada semester II tahun ini, dikarenakan masyarakat akan mulai memperioritaskan produk kesehatan dan pelayanan kesehatan di tengah pandemi virus corona (Katadata, 2020). Selain masalah pandemi yang dihadapi industri rumah sakit di Indonesia, beberapa pengelolanya juga mengeluhkan adanya keterlambatan pencairan klaim jaminan kesehatan milik pemerintah yaitu BPJS (Badan Penyelenggara Jaminan Sosial) (Kontan, 2020).

Keterlambatan dari pembayaran klaim jaminan kesehatan dapat memperngaruhi likuiditas dan solvabilitas dari perusahaan. Dikutip dari artikel situs berita Katadata, keterlambatan pengembalian dana klaim menyebabkan terganggunya aktivitas di industri rumah sakit. Wakil ketua ARSSI (Asosiasi Rumah Sakit Swasta Indonesia) berpendapat mengenai keterlambatan pembayaran klaim oleh BPJS kesehatan, menyebabkan rumah sakit swasta berhutang kepada bank untuk bisa menutupi kekurangan di aliran kas. Namun yang dikhawatirkan oleh pihak rumah sakit swasta, apabila hutang kepada bank sudah jatuh tempo, bunganya juga harus diperhitungkan oleh pihak rumah sakit (Katadata, 2019).

Pada kondisi pandemi corona tidak sedikit perusahaan-perusahaan yang mengalami penurunan harga sahamnya, bahkan dituliskan di dalam artikel Kompas (2020), performa IHSG dikatakan melemah dikarenakan pandemi ini. Dikatakan di dalam artikel tersebut hal ini disebabkan oleh para investor memindahkan asetnya ke instrument investasi yang lebih aman. Walaupun dikatakan pendapatan industri rumah sakit menurun, dalam artikel Bisnis.com (2020), dituliskan bahwa saham emiten rumah sakit menguat ditengah melemahnya IHSG. Harga saham unit usaha dapat menggambarkan nilai perusahaan dari unit usaha tersebut. Semakin kecil nilai perusahaan maka semakin kecil harga sahamnya. Rumah sakit memiliki model bisnis seperti perusahaan lainnya, namun rumah sakit memiliki tanggung jawab sosial yaitu memberikan pelayanan kesehatan yang menjadi salah satu kebutuhan pokok masyarakat. Terutama kondisi pandemi corona, kesehatan menjadi perhatian khusus bagi masyarakat.

Dari latar belakang diatas, adanya perbedaaan performa harga saham harga saham industri rumah sakit dengan perusahaan lainnya, dan terbatasnya penelitian di Indonesia yang membahas tentang nilai perusahaan rumah sakit. Maka penelitian ini bertujuan agar mengetahui faktor-faktor internal yang 
mempengaruhi nilai perusahaan dari industri rumah sakit. Nilai perusahaan dipengaruhi oleh beberapa faktor internal dan eksternal unit usaha tersebut. Faktor internal yang dimaksud bisa dalam berupa profitabilitas, solvabilitas, likuiditas, dan komponen laporan perusahaan lainnya.

Berliana, F. (2018), menemukan profitabilitas memiliki hubungan positif dan berpengaruh signifikan terhadap nilai perusahaan, hal ini didukung dengan penelitian yang dilakukan oleh Sari, I. A. G. D. M. (2020), Hapsoro, D. (2020), Syafuddin, D. (2019), dan Ayu, D. P. (2017). Sedangkan Hendayana, Y. (2019) mengatakan profitabilitas memiliki hubungan positif dan tidak berpengaruh signifikan terhadap nilai perusahaan. Maka dari hasil telaah penelitian sebelumnya, maka hipotesis yang digunakan sebagai berikut.

$\mathrm{H}_{1}$ : Profitabilitas memiliki pengaruh signifikan dan hubungannya positif terhadap nilai perusahaan.

Itsnaini, H. M. (2017) mengatakan bahwa solvabilitas memberikan pengaruh signifikan kepada nilai perusahaan, hal ini satu pendapat dengan Berliana, F. (2017), dan Aditya Permana, A. A. N. B. (2019). Maka dari hasil telaah penelitian sebelumnya, maka hipotesis yang digunakan sebagai berikut.

$\mathrm{H}_{2}$ : Solvabilitas memiliki pengaruh signifikan dan hubungannya negatif terhadap nilai perusahaan.

Pada penelitian Santania, A. (2020) menemukan bahwa liquiditas berdampak signifikan kepada nilai perusahaan, hal ini sejalan dengan Hendayana, Y. (2019), Mareta S. (2019) dan Aditya Permana, A. A. N. B. (2019). Maka dari hasil telaah penelitian sebelumnya, maka hipotesis yang digunakan sebagai berikut.

$\mathrm{H}_{3}$ : Liquiditas memiliki pengaruh signifikan dan hubungannya negatif terhadap nilai perusahaan.

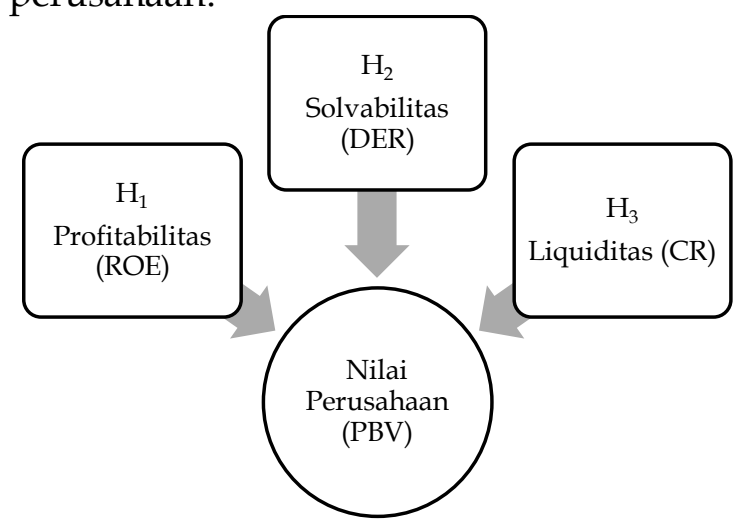

Gambar 1. Model Penelitian

Sumber: Data Penelitian, 2020

\section{METODE PENELITIAN}

Model penelitian ini merupakan replikasi atas penelitian sebelumnya milik Aditya Permana, A. A. N. B. dan Henny R. tahun 2019 yang berjudul Pengaruh profitabilitas, solvabilitas, likuiditas dan inflasi terhadap nilai perusahaan. Jurnal penelitian tersebut mengangkat tentang Pengaruh Profitabilitas, Solvabilitas, Likuiditas, Dan Inflasi Terhadap Nilai Perusahaan pada Manufaktur Sektor Logam yang terdaftar di IDX periode 2014-2016. Penelitian tersebut memakai 
variabel bebas profitabilitas diwakilkan oleh ROE, solvabilitas diwakilkan oleh DER, likuiditas diwakilkan oleh $C R$, nilai inflasi dan variabel terikatnya nilai perusahaan diwakilkan oleh PBV.

Pada penelitian ini memfokuskan pada faktor internal didalam perusahaan dan tidak memakai faktor makroekonomi, sehingga variabel yang dipakai yaitu:

Profitabilitas dengan definisi kapasitas bisnis untuk membuat keuntungan dari penjualan atau investasi (Rehman, 2014). Profabilitas diwakilkan oleh ROE. ROE merupakan gambaran bagaimana performa perusahaan terhadap modal perusahaan. Satuan pengukuran ROE adalah persentase (\%).

$\mathrm{ROE}=\frac{\text { Laba bersih setelah Pajak }}{\text { Modal Perusahaan }} \times 100 \%$

Solvabilitas dengan definisi kapasisitas bisnis untuk membayar liabilitas jangka menengah dan panjang (Douglas, 2014). Solvabilitas diwakilkan oleh DER. DER merupakan perbandingan antara total hutang perusahaan dengan modal perusahaan. Satuan pengukuran DER adalah persentase (\%).

DER $=\frac{\text { Total Hutang }}{\text { Modal Perusahaan }} \times 100 \%$

Likuiditas dengan definisi kapasisitas bisnis untuk membayar liabilitas jangka pendek (Douglas, 2014). Likuiditas diwakilkan oleh CR. CR merupakan perbandingan antara aset lancar dengan hutang lancar. Satuan pengukuran $C R$ adalah persentase (\%).

$\mathrm{CR}=\frac{\text { Aset lancar }}{\text { Kewajiban lancar }} \times 100 \%$

Nilai Perusahaan merupakan nilai yang sering dikaitkan dengan harga saham sebuah perusahaan go-public, sedangkan perusahaan swasta terletak pada aset dan prospek jangka panjang perusahaan tersebut (Margareta, 2011). Nilai perusahaan diwakilkan oleh PBV. PBV merupakan hasil perbandingan antara harga saham dengan nilai buku. Satuan pengukuran PBV yaitu persentase (\%).

$\mathrm{PBV}=\frac{\text { harga perlembar saham }}{\text { nilai buku per lembar saham }} \times 100 \%$

Penelitian ini menggunakan pendekatan kuantitatif. Populasi Penelitian ialah rumah sakit berada pada sektor 9 Trade, subsektor 96 health di BEI periode 2015-2019. Sampel Selection yang digunakan teknik Non-Random Sampling dengan metode Purposive Sampling. Perusahaan yang diteliti yaitu, RS Siloam (SILO), RS Omni (SAME), RS Mitra Keluarga (MIKA), dan RS Mayapada (SRAJ). Penelitian ini memakai teknik analisis regresi data panel, sehingga menghasilkan nilai yang berlainan pada masing-masing sampel perusahaan dan periode. Pemilihan metode regresi data panel, karena diasumsikan setiap perusahaan memiliki karakter individu yang berbeda dan setiap perbedaan periode kemungkinan terdapat faktor yang mempengaruhi tetapi tidak masuk ke dalam penelitian ini. Asumsi perbedaan ini akan terlihat pada parameter variabel, intersep dan variabel gangguannya.

Berikut ini adalah persamaan regresi penelitian ini yang akan dipakai sebagai berikut.

$\mathrm{PBV}_{\text {it }}=\alpha+\beta_{1} \mathrm{ROE}_{i t}+\beta_{2} \mathrm{DER}_{i t}+\beta_{3} \mathrm{CR}_{i t}+\varepsilon_{i \mathrm{t}}$

Keterangan:

$\propto \quad:$ Intersep

$\beta \quad$ : Parameter untuk variabel bebas

$\varepsilon_{\text {it }} \quad$ : Komponen error periode t untuk individu sampel i 
i : Urutan sampel yang diobservasi (MIKA, SAME, SILO, SRAJ)

t $\quad$ : Time Series (2015Q1, 2015Q2, ..., 2019Q4)

\section{HASIL DAN PEMBAHASAN}

Berikut ini menunjukan nilai MIN, MAX, Mean, yang diproses dengan Eview dari data variable bebas maupun terikat.

Tabel 1. Statistik Deskriptif

\begin{tabular}{lllll}
\hline & ROE & DER & CR & PBV \\
\hline Mean & 0.044988 & 0.512326 & 3.325059 & 4.385902 \\
Median & 0.031831 & 0.391056 & 1.610398 & 2.857602 \\
Maximum & 0.246482 & 1.826922 & 12.73088 & 13.84275 \\
Minimum & -0.143499 & 0.076651 & 0.514860 & 0.678080 \\
Std. Dev. & 0.081862 & 0.366487 & 3.484935 & 3.525157 \\
Skewness & 0.437170 & 1.256547 & 1.485072 & 0.940189 \\
Kurtosis & 2.928997 & 4.814640 & 3.812481 & 2.672212 \\
Jarque-Bera & 2.565034 & 32.02853 & 31.60626 & 12.14421 \\
Probability & 0.277338 & 0.000000 & 0.000000 & 0.002306 \\
Sum & 3.599065 & 40.98609 & 266.0047 & 350.8721 \\
Sum Sq. Dev. & 0.529410 & 10.61070 & 959.4368 & 981.7118 \\
Observations & 80 & 80 & 80 & 80 \\
Cross sections & 4 & 4 & 4 & 4 \\
\hline
\end{tabular}

Sumber: Data Penelitian, 2020

Dari Tabel 1, pada uji deskriptif, didapatkan jumlah data observasi ialah 80 da data cross sections ialah empat, Mean PBV adalah 4.3858 dengan standard devation 3.5247, Mean ROE adalah 0.0450 dengan standard devation 0.08186, Mean DER adalah 0.5123 dengan standard devation 0.36649, dan Mean CR adalah 3.3251 dengan standard devation 3.48494. Nilai minimum ROE sebesar -0.14 dimiliki oleh RS Omni (SAME) pada periode Q4 2019 dan nilai maksimum ROE sebesar 0.25 dimiliki oleh RS Mitra Keluarga (MIKA) pada periode Q4 2016. Nilai minimum DER sebesar 0.08 dimiliki oleh RS Mitra Keluarga (MIKA) pada periode Q2 2019 dan nilai maksimum DER sebesar 1.83 dimiliki oleh RS Mitra RS Omni (SAME) pada periode Q3 2015. Nilai minimum CR sebesar 0.51 dimiliki oleh RS Omni (SAME) pada periode Q4 2019 dan nilai maksimum CR sebesar 12.73 dimiliki oleh RS Mitra Keluarga (MIKA) pada periode Q4 2015. Nilai minimum PBV sebesar -0.68 dimiliki oleh RS Omni (SAME) pada periode Q1 2017 dan nilai maksimum PBV sebesar 13.84 dimiliki oleh RS Mitra Keluarga (MIKA) pada periode Q3 2015. Nilai negatif yang dimiliki oleh SRAJ dikarenakan perusahaan mengalamai kerugian sejak 2015 hingga 2019 menurut laporan tahunan yang didapatkan dari BEI.

Berikut pemilihan model estimasi; (1) Dari chow test didapatkan nilai probabilitas F di bawah lima persen atau 0,05 yaitu 0,0000 maka diartikan Model Estimasi FEM lah yang paling baik pada penelitian ini; (2) Dilanjukan Hausman test, didapatkan nilai probabilitas chi-square di bawah lima persen atau 0,05 yaitu 0,0000 maka diartikan Model Estimasi FEM lah yang paling baik dilakukan pada penelitian ini. Dari hasil pemilihan model estimasi yang paling baik digunakan pada penelitian ini adalah FEM, maka penelitian ini dapat dilanjutkan untuk analisis berikutnya. 
Tabel 2. Fixed Effect Model (FEM)

\begin{tabular}{|c|c|c|c|c|}
\hline Variable & Coefficient & Std. Error & $t$-Statistic & Prob. \\
\hline ROE & 3.767648 & 3.925509 & 0.959786 & 0.3403 \\
\hline DER & 3.712137 & 0.832254 & 4.460340 & 0.0000 \\
\hline $\mathrm{CR}$ & 0.377668 & 0.137515 & 2.746366 & 0.0076 \\
\hline $\mathrm{C}$ & 1.058810 & 0.671680 & 1.576361 & 0.1193 \\
\hline \multicolumn{5}{|l|}{ Fixed Effects (Cross) } \\
\hline _MIKA--C & 3.730659 & & & \\
\hline _SAME--C & -3.121377 & & & \\
\hline _SILO--C & 0.694458 & & & \\
\hline _SRAJ--C & -1.303740 & & & \\
\hline \multicolumn{5}{|c|}{ Effects Specification } \\
\hline \multicolumn{5}{|c|}{ Cross-section fixed (dummy variables) } \\
\hline Root MSE & 1.617671 & $R$-squared & & 0.786751 \\
\hline Mean dependent var & 4.385902 & Adjusted R-squared & & 0.769224 \\
\hline S.D. dependent var & 3.525157 & S.E. of regression & & 1.693455 \\
\hline Akaike info criterion & 3.974852 & Sum squared resid & & 209.3487 \\
\hline Schwarz criterion & 4.183279 & Log likelihood & & -151.9941 \\
\hline Hannan-Quinn criter. & 4.058416 & F-statistic & & 44.88722 \\
\hline Durbin-Watson stat & 0.554652 & Prob(F-statistic) & & 0.000000 \\
\hline
\end{tabular}

Sumber: Data Penelitian, 2020

Nilai Sig. probabilitas F didapatkan kurang dari lima persen atau 0,05 yaitu 0,00000, dapat diartikan Profitabilitas dengan ROE, Solvabilitas diwakilkan DER, dan Likuiditas diwakilkan CR secara bersama-sama mempengaruhi Nilai Perusahaan yang diawakilkan PBV secara signifikan pada keempat pengelola industri rumah sakit.

Nilai Adjusted $R$ Square ialah 0,769224 dalam kata lain variabel ROE, DER, dan CR memiliki pengaruh berkekuatan $76,9 \%$ terhadap variabel PBV dan sisanya $23,1 \%$ oleh variabel bebas lainnya yang tidak masuk dalam model penelitian ini.

Nilai Sig. ROE 0,3403 di atas lima persen atau 0,05, sedangkan Sig. DER 0,0000, dan Sig. CR 0,0076 di bawah lima persen atau 0,05. Untuk melihat hubungan diperlukan uji t parsial berdasarkan nilai $\mathrm{T}_{\text {hitung }}$ dan $\mathrm{T}_{\text {tabel. }}$.

Untuk mendapatkan nilai $\mathrm{T}_{\text {hitung }}$ untuk uji parsial diperoleh dari nilai $\mathrm{t}$ setiap variabel, yaitu; ROE $\mathrm{T}_{\text {hitung }}$ Profitabilitas adalah 0,959786; DER $\mathrm{T}_{\text {hitung }}$ Solvabilitas adalah 4,460340; dam CR Thitung Likuiditas adalah 2,74636

Kemudian untuk mendapatkan nilai $\mathrm{T}_{\text {tabel }}$ dengan cara menggunakan persamaan berikut:

$\mathrm{T}_{\text {tabel }}=\left(\frac{\alpha}{2} ; \mathrm{N}-\mathrm{k}-1\right)$

a adalah nilai signifikansi $0,05, \mathrm{~N}$ adalah jumlah banyaknya sampel 80 data dari semua variabel dan $\mathrm{k}$ adalah jumlah variabel bebas atau $\mathrm{X}$ yaitu 3 . Setelah didapatkan $\mathrm{T}_{\text {tabel }}$ yaitu $(0,025 ; 76)$ maka dimasukan kedalam distribusi tabel t. Maka didapatkan nilai titik potong dari table T adalah 1,99167. Maka apabila nilai variabel bebas kurang dari $(<)-1,99167$ maka bisa dikatakan variabel bebas berada di posisi signifikasi dan berhubungan negatif terhadap variabel terikat. Sedangkan apabila variabel bebas berada lebih dari (>) 1,99 maka bisa dikatakan variabel bebas berada di posisi signifikan dan 
berhubungan positif terhadap variabel terikat. Tetapi apabila berada diantara 1,99167 dan 1,99167 maka variabel indipenden tidak signifikan mempengaruhi variabel terikat.

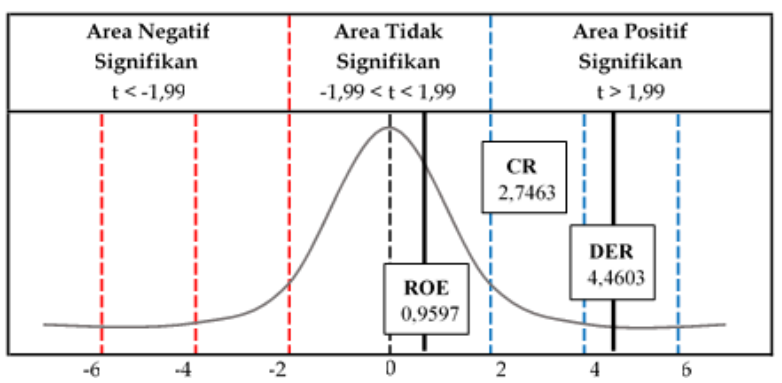

Gambar 2. Kurva Regresi Uji t Parsial

Sumber: Data Penelitian, 2020

Dari Gambar 2, kurva regresi uji t parsial maka dapat diambil keputusan sebagai berikut.

$\mathrm{ROE}=$ Profitabilitas dengan proxi Return on Equity (ROE) tidak berpengaruh signifikan dan memiliki hubungan positif terhadap Nilai Perusahaan dengan proxi Price to Book Value Ratio (PBV)

DER = Solvabilitas dengan proxi Debt to Equity Ratio (DER) berpengaruh signifikan dan memiliki hubungan positif terhadap Nilai Perusahaan dengan proxi Price to Book Value Ratio (PBV)

$\mathrm{CR}=$ Likuiditas dengan proxi Current Ratio (CR) berpengaruh signifikan dan memiliki hubungan positif terhadap Nilai Perusahaan dengan proxi Price to Book Value Ratio (PBV)

Dari hasil uji t parsial berdasarkan signifikansi didapatkan nilai DER, dan CR mempengaruhi PBV secara signifikan, sedangkan ROE tidak signifikan mempengaruhi PBV. Menurut posisi dari kurva regresi uji t parsial, didapatkan ROE, CR, dan DER mengarah nilai postif. 10

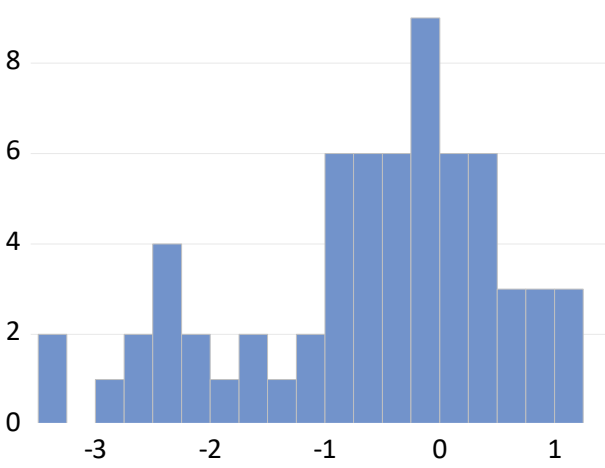

Gambar 3. Uji Normalitas

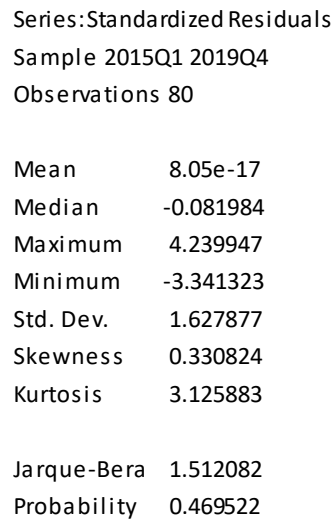

Sumber: Data Penelitian, 2020

Dari Gambar 3, didapatkan nilai JB yaitu 1,512082 dan nilai probabilitas JB 0,469522. Karena nilai probabilitas JB pada penelitian berada di atas lima persen atau 0,05 dengan kata lain distribusi data residual nomal. 
Untuk uji multikolineritas pada penelitian ini, menggunakan tabel nilai kolerasi antar variabel. Titik potong nilai kolerasi yaitu 0,80. Maka didapatkan nilai kolerasi antar variabel yaitu:

Tabel 3. Uji Multikolinearitas

\begin{tabular}{cccc}
\hline & ROE & DER & CR \\
\hline ROE & 1 & -0.2523430413239032 & 0.7131459696005882 \\
DER & -0.2523430413239032 & 1 & -0.525460862594892 \\
CR & 0.7131459696005882 & -0.525460862594892 & 1 \\
\hline
\end{tabular}

Sumber: Data Penelitian, 2020

Dari Tabel 3, didapatkan nilai kolerasi antar variabel bebas yaitu ROE, DER, dan CR memiliki di bawah nilai 0.8, maka dari hasil tersebut dapat diambil kesimpulan data yang dipakai tidak memiliki gejala multikolineritas.

Tabel 4. Uji Heteroskedasitas

\begin{tabular}{ccccc}
\hline Variable & Coefficient & Std. Error & t-Statistic & Prob. \\
\hline ROE & -0.570546 & 4.680707 & -0.121893 & 0.9033 \\
DER & -1.310163 & 0.992365 & -1.320243 & 0.1909 \\
CR & -0.130237 & 0.163971 & -0.794270 & 0.4296 \\
C & -1.918837 & 0.800899 & -2.395853 & 0.0191 \\
\hline
\end{tabular}

Sumber: Data Penelitian, 2020

Uji heteroskedasitas yang dipakai ialah Uji Park. Maka didapatkan nilai variabel profitabilitas adalah 0,9033, solvabilitas adalah 0,1909 dan likuiditas adalah 0,4296. Nilai probabilitas masing-masing variabel berada diatas 0,05. Maka dari hasil ini dapat dikatakan pada penelitian ini tidak ada gejala heteroskedastisitas.

Pada uji autokorelasi didapatkan Durbin-Watson (DW) 0,554652. Karena nilai DW tersebut diposisi antara -2 dengan +2 , maka dapat disimpulkan data yang dipakai tidak memiliki gejala autokorelasi.

Berikut ini adalah persamaan yang diperoleh berdasarkan model yang terpilih yaitu estimasi FEM sebagai berikut:

$P B V_{\mathrm{i}}=\mathrm{a}+\beta_{1} R O E+\beta_{2} D E R+\beta_{3} C R+\sum_{\mathrm{i}=1}^{4} \propto_{\mathrm{i}} \mathrm{D}_{\mathrm{i}}+\varepsilon_{\mathrm{i}}$

Kemudian berikut persamaan regresi data panel dengan menggunakan rumus FEM untuk keseluruhan sampel:

$P B V_{i}=1.058810+(3.767648) R O E+(3.712137) D E R+(0.377668) C R+$ $\sum_{i=1}^{4} \propto_{i} D_{i}+\varepsilon_{i}$

Untuk mendapatkan persamaan regresi masing-masing sampel dengan memasukkan nilai intersep sampel masing-masing ke komponen $\propto_{i} D_{i}$, yaitu:

(1) MIKA : Nilai $\propto_{i} D_{i}=3,730659$

(2) SAME : Nilai $\propto_{i} D_{i}=-3,121377$

(3) SILO : Nilai $\propto_{i} D_{i}=0,694458$

(4) SRAJ : Nilai $\propto_{i} D_{i}=-1,303740$

Dengan melihat nilai intersep dari masing-masing sampel yang berbeda-beda menunjukan keadaan masing-masing sampel yang tidak konstan atau sama. Intersep ini menandakan adanya variabel-variabel lain yang mempengaruhi PBV tetapi tidak masuk kedalam persamaan. Apabila diasumsikan seluruh Variabel indipenden $(X)$ konstan atau sama dengan nol, 
maka akan terlihat kondisi Variabel dependen (Y) Nilai perusahaan setiap individu.

Setelah dilakukan pengelolaan data dengan $a l p h a=5 \%$, maka diperoleh hasil uji regresi sebagai berikut.

Interpretasi Variabel Profitabilitas (ROE) terhadap Nilai Perusahaan (PBV): Nilai koefisien regresi variabel ROE sebesar 3,767648 nilai yang positif menunjukkan adanya hubungan searah antara PBV dengan ROE, jika ROE meningkat sebesar satu satuan sementara variabel lainnya diasumsikan konstan atau sama dengan nol, maka nilai perusahaan akan meningkat sebesar 3,767648 dengan standard error 3,925509. Dapat disimpulkan bahwa Profitabilitas mempunyai hubungan searah dengan Nilai Perusahaan.

Interpretasi Variabel Solvabilitas (DER) terhadap Nilai Perusahaan (PBV): Nilai koefisien regresi variabel DER sebesar 3,712137 nilai yang positif menunjukkan adanya hubungan yang searah antara PBV dengan DER, jika DER meningkat sebesar satu satuan sementara variabel lainnya diasumsikan konstan atau sama dengan nol, maka nilai perusahaan akan meningkat sebesar 3,712137 dengan standard error 0,832254. Dapat disimpulkan bahwa Solvabilitas mempunyai hubungan searah dengan Nilai Perusahaan.

Interpretasi Variabel Likuiditas (CR) terhadap Nilai Perusahaan (PBV): Nilai koefisien regresi variabel $C R$ sebesar 0,377668 nilai yang positif menunjukkan adanya hubungan yang searah antara nilai perusahaan dengan CR, jika CR meningkat sebesar satu satuan sementara variabel lainnya diasumsikan konstan atau sama dengan nol, maka nilai perusahaan akan meningkatkan 0,377668 dengan standard error 0.137515. Dapat disimpulkan bahwa Likuiditas mempunyai hubungan searah dengan Nilai Perusahaan.

Laporan tahunan keuangan adalah salah satu instrument yang dipakai investor untuk mengukur sebuah perusahaan sebelum mengambil keputusan untuk bertransaksi saham perusahaan di pasar modal. Pada penelitian ini menganalisis pengaruh dari profitabilitas, solvabilitas dan liquiditas dari industri rumah sakit yang terdaftar pada BEI periode 2015 hingga 2019. Berikut adalah ringkasan hipotesis setelah dilakukan analisis.

Tabel 5. Ringkasan hipotesis setelah pengolahan data

\begin{tabular}{ccccc}
\hline & Proxi & Hipotesis & Hasil & Simpulan \\
\hline Y & PBV & & & \\
ROE & ROE & Signifikan \& Positif & Tidak Signifikan \& Positif & $\mathrm{H}_{1}$ ditolak \\
DER & DER & Signifikan \& Negatif & Signifikan \& Positif & $\mathrm{H}_{2}$ ditolak \\
CR & CR & Signifikan \& Negatif & Signifikan \& Positif & $\mathrm{H}_{3}$ ditolak \\
\hline
\end{tabular}

Sumber: Data Penelitian, 2020

Hasil penelitian ini menunjukan bahwa ROE tidak mempengaruhi signifikan dan berhubungan positif terhadap PBV sehingga H1 ditolak. Pada penelitian ini nilai standard error ROE sangatlah besar dibandingkan dengan variabel lainnya, sehingga untuk memprediksi PBV kedepannya dengan menggunakan persamaan regresi akan mendapat angka yang tidak akurat. Hasil penelitian ini searah dengan penelitian Wawan C. Nugroho (2017), Priyanto, S. (2016) yang menegaskan profitabilitas tidak mempengaruhi signifikan nilai perusahaan. Di Negara Amerika Serikat dikatakan, pengelolaan industri rumah sakit mendapat keuntungan yang sangat sedikit, dan banyak rumah sakit yang 
justru mengalami kerugian (NBC, 2018). Menurut Sam Richardson, pakar ekonomi kesehatan di Amerika Serikat, itu merupakan hal wajar, beberapa cabang rumah sakit mendapat keuntungan yang besar dan beberapa cabangnya tidak. Tantangannya yang ada adalah, bagaimana membiayai cabang rumah sakit yang untung lebih sedikit tanpa harus memberhentikan cabang rumah sakit yang mengalami kerugian. Hal ini pun terjadi pada industri rumah sakit Indonesia, beberapa cabang rumah sakit mendapat keuntungan, namun keuntungan tersebut dipakai untuk subsidi silang atau melunasi kewajiban cabang rumah sakit lainnya.

Hasil penelitian ini menunjukan DER berpengaruh signifikan dan memiliki hubungan positif dengan PBV sehingga $\mathrm{H} 2$ ditolak. Hal ini menunjukan bahwa investor memperhatikan besar liabilitas jangka panjang yang dimiliki perusahaan. Besar atau kecilnya beban hutang yang ditanggung perusahaan dapat mengurangi keuntungan yang diterima oleh perusahaan. Solvabilitas dilihat bersamaan dengan prospek perusahaan, pada rumah sakit modern, mereka memajukan rumah sakitnya tidak hanya dengan mengandalkan keuntungan tetapi juga dengan pinjaman jangka panjangnya. Hasil ini sama dengan penelitian sebelumnya, Ryan A. Wijaya (2020) dan Michael Anderson Sianipar (2019) didapatkan Sovency berpengaruh signifikan dan memiliki hubungan positif dengan nilai perusahaan.

Dari pembahasan didapatkan $\mathrm{H} 3$ ditolak dan disimpulkan bahwa CR berpengaruh signifikan dan berhubungan positif terhadap PBV industri rumah sakit di BEI. Kecilnya rasio CR menandakan masalah dalam likuidasi atau pengelolaan kas. Besar kecil nya pelunasan kewajiban perusahaan akan memberikan pengaruh tingkat pengembalian pemilik saham perusahaan, dan secara tidak langsung mempengaruhi nilai perusahaan. Hasil ini searah dengan penelitian sebelumnya Yudha D. Putra (2013) dan Ida Ayu Sri Uttari (2018) yang mendapatkan CR berpengaruh signifikan dan berhubungan positif. Pada CR memiliki nilai standard error terkecil dibandingkan variabel lainnya, dan nilainya mendekati angka nol, dalam kata lain apabila saat memprediksi CR perusahaan dengan menggunakan persamaan regresi dipenelitian, akan didapatkan nilai yang mendekati akurat. Di negara Indonesia, dikatakan oleh perwakilan dari pengelola industri rumah sakit swasta, bahwa keterlambatan pembayaran klaim BPJS keseharan, menyebabkan kas perusahaan menurun banyak, Sehingga untuk dapat memberikan pelayanan kesehatan, rumah sakit swasta harus melakukan pinjaman kepihak ke tiga. Karena industri rumah sakit memerlukan jumlah kas yang tinggi, terutama berkaitan dengan sistem asuransi, berbeda dengan perusahaan lainnya.

Pada penelitian ini didapatkan nilai intersep positif terbesar dimiliki oleh MIKA, sedangkan nilai intersep negatif terbesar dimiliki oleh SAME. Pada penelitian ini dapat dilihat nilai instersep SILO mendekati angka nol dibandingkan intersep sampel lainnya. Pada penelitian ini secara bersama-sama ROE, DER dan CR mempengaruhi signifikan terhadap PBV pada keempat industri rumah sakit yang terdaftar di IDX dan aktif periode 2015-2019.

Dari hasil koefesien determinan ROE, DER, dan CR memiliki kekuatan $76,9 \%$ terhadap PBV. sisanya sekitar $23,1 \%$ dipengaruhi variabel lainnya yang tidak masuk dalam model penelitian ini. 


\section{SIMPULAN}

Berdasarkan hasil pengolahan data dengan pendekatan FEM regresi data panel yang telah dikumpulkan melalui dokumen laporan tahunan keuangan pengelolaan rumah sakit yang terdaftar dan aktif di IDX periode 2015-2019, maka didapatkan nilai p dari ROE 0.3403, DER 0.0000 dan CR 0.0076. ROE, DER dan CR memiliki koefisien regresi positif. Nilai intersep MIKA 3,37330659, SAME 3,121377, SILO 0,694458, dan SRAJ -1,303740.

Keterbatasan dan kekurangan dalam penelitian ini diantaranya adalah penelitian ini kekuatan pengaruh variabel ROE, DER dan CR terhadap PBV belum $100 \%$ masih $76,2 \%$. Diharapkan untuk penelitian selanjutnya bisa menambah variabel lain untuk bisa meningkatkan kekuatan variabel agar mendekati $100 \%$. Penelitian ini juga dilakukan dengan menggunakan laporan keuangan, tidak mencatat laporan secara real time, sehingga kita tidak tahu secara langsung bagaimana kondisi perusahaan tersebut, apakah sedangkan dalam pembangunan atau sedang perbaikan. Saran untuk penelitian berikutnya, melakukan pendataan secara langsung dan melihat apa yang sedang terjadi di saat adanya perubahaan, atau mewawancara divisi keuangan rumah sakit tersebut.

\section{REFERENSI}

Abrori, A., Suwitho (2018). Pengaruh Profitabilitas, Likuiditas, solvabilitas terhadap nilai perusahaan. Indonesia: Jurnal ilmu dan Riset manajemen.

Agusta, R. F., \& Hati S. W. (2018), Calculation of liquidity, solvency and profitability ratio in manufacturing company. Indonesia: Journal of applied accounting and taxation. Vol 3 (2)

Agustina, A. (2020) IDN. Daftar Emiten Farmasi dan Rumah Sakit yang Bisa Menaklukkan IHSG. Diuduh pada tanggal 4 Desember 2020 dari https://www.idntimes.com/business/economy/auriga-agustina-3/daftaremiten-farmasi-dan-rumah-sakit-yang-bisa-menaklukkan-ihsg.

Alika, R. (2020) Katadata. Jokowi Hitung Dampak Ekonomi Corona, Sopir Angkot \& Ojek Paling Berat. Diuduh pada tanggal 4 desember 2020 dari https://katadata.co.id/desysetyowati/berita/ 5e9a421299d8f/jokowihitung-dampak-ekonomi-corona-sopir-angkot-ojek-paling-berat.

Altstedter, A. (2019) India Times. Apollo Hospitals seeks investor, asset sales to cut debt. diakses pada tanggal 5 Desember 2020 dari https://economictimes.indiatimes.com/markets/stocks/news/ apollohospitals-seeks-investor-asset-sales-to-cut-debt/articleshow /

70256783.cms?utm_source $=$ contentofinterest\&utm_medium $=$ text\&utm_ campaign $=$ cppst

Ayu, D. P., \& Suarjaya, A. A. G. (2017). Pengaruh profitabilitas terhadap nilai perusahaan dengan corporate social responsibility sebagai variabel mediasi pada perusahaan pertambangan. E-Jurnal Manajemen Universitas Udayana, $8(3)$.

Azka, R. M. (2020) Bisnis.com. IHSG Boncos, Saham Emiten Rumah Sakit Tetap Berpesta. Diuduh pada tanggal 4 Desember 2020 dari https://market.bisnis.com/read/ 20210315/7/1367794/ihsg-boncos-saham- 
emiten-rumah-sakit-tetap-berpesta.

Badan Penyelenggara Jaminan Sosial (2018). Administrasi Klaim Fasilitas Kesehatan BPJS Kesehatan Diuduh pada tanggal 5 Desember 2020 dari https://bpjs-kesehatan.go.id/bpjs/dmdocuments/5fb1dc8414591e392ab5a3 f70e2ab35a. pdf.

Badan Pusat Statistik. (2020). Berita resmi statistic. Diuduh pada tanggal 5 Desember 2020 dari https://www.bps.go.id/website/ materi_ind/materiBrsInd-20200205114932_.pdf

Berliana, F., Darwin, L., Jubi, \& Astuti (2018). Pengaruh solvabilitas dan profitabilitas terhadap nilai perusahaan pada perusahaan sub sector pertambangan batubara yang terdaftar di bursa efek Indonesia. Indonesia: Jurnal Akuntansi, Financial, 4(1).

Brigrham, E., Houston, \& Yulianto, A. A. (2006). Dasar-dasar manajemen keuangan, edisi sepuluh: Fundamentals of Financial Management. Jakarta: Salemba Empat.

Bursa Efek Indonesia. (2020). Laporan Keuangan industri rumah sakit yang sudah go-public. Diuduh pada tanggal 5 Desember 2020 dari https://www.idx.co.id/perusahaan-tercatat/laporan-keuangan-dantahunan/

Celmia, Mardani R. M., \& Salim A. (2017). Pengaruh pertumbuhan asset, keputusan pendanaan, kebijakan dividen dan tingkat inflasi terhadap nilai perusahaan (studi empiris pada perusahaan property dan real estate yang terdaftar di Bursa Efek Indonesia pada tahun 2014-2016). Indonesia: Prodi Manajemen.

Curtis, P, \& Roupas, T. A. (2009). Health Care Finance, the Performance of Public Hospitals and Financial Statement Analysis. European Research Studies, 12(4), 199-212.

Douglas, O., Xudong, C., \& Tang, T. (2014). The effect of liquidity and solvency risk on the inclusion of bond covenants. Journal of Banking $\mathcal{E}$ Finance, 48, 120136.

Erlina, N., (2018). Pengaruh likuiditas, solvabilitas, profitabiltas terhadap nilai perusahaan pertambangan dibursa efek Indonesia. Jurnal Manajemen Kompeten Vol 1 (1).

Fajrian, H. (2019) Katadata. Pembayaran Klaim BPJS Telat, Asosiasi Rumah Sakit Swasta Adukan ke DPR. Diuduh pada tanggal 4 desember 2020 dari https://katadata.co.id/happyfajrian/berita/ 5e9a4e55085c7/pembayaranklaim-bpjs-telat-asosiasi-rumah-sakit-swasta-adukan -ke-dpr.

Fadliansyah, M. E. (2020) Katadata. Pasien Takut Datang karena Corona, Bisnis RS di Semester I Terpuruk. Diuduh pada tanggal 4 desember 2020 dari https://katadata.co.id/happyfajrian/finansial/ 5f436b3ca73a0/pasientakut-datang-karena-corona-bisnis-rs-di-semester-i-terpuruk.

Ferrouhi, E. M. (2014). Liquidity and solvency in the international banking regulation. Morocco: Université Ibn Tofail.

Ghozali, I., Hengky L. (2015). Konsep, Teknik, Aplikasi Menggunakan Smart PLS 3.0 Untuk Penelitian Empiris. Semarang: BP Undip.

Haefner, M. (2018). Becker's Hospital Review. 9 private equity firms gobbling up healthcare businesses. Diakses pada tanggal 7 januari 2021 dari https://www.beckershospitalreview.com/hospital-transactions-and- 
valuation/9-private-equity-firms-gobbling-up-healthcare-businesses.html

Hamidah, Hartini, \& Mardiyati, U. (2015). Pengaruh Inflasi, suku bunga bi, profitabilitas dan risiko finansial terhadap nilai perusahaan sektor properti tahun 2011-2013. JRMSI, 6(1).

Hapsoro, D., \& Falih, Z. N. (2020). The effect of firm size, profitability, liquidity on the firm value moderated by carbon emission disclosure. Journal of Accounting and Investment Vol 21 (2).

Hendayana, Y., \& Riyanti N. (2019). Pengaruh inflasi, suku bunga, likuiditas, dan leverage terhadap nilai perusahaan. Jakarta: Kinerja, 2(1).

Itsnaini, H. M., \& Subardjo, A. (2017) Pengaruh profitabilitas dan solvabilitas terhadap nilai perusahaan yang dimoderasi corporate social responsibility. Jurnal Ilmu dan Riset Akuntasi Vol 6 (6).

Kementrian Kesehatan Republik Indonesia. (2019). Data dan informasi profil Kesehatan Indonesia 2019. Diuduh pada tanggal 4 desember 2020 dari https://www.kemkes.go.id/ resources/download/pusdatin/profilkesehatan-indonesia/Data-dan -Informasi_Profil-Kesehatan-Indonesia2019.pdf.

Lapointe, J. (2018) Revcycle Intelligence. 4 Hospital Business Models for Consumer-Centric Healthcare. Diakses pada tanggal 7 Januari 2021 dari https://revcycleintelligence.com/news/4-hospital-business-models-forconsumer-centric-healthcare.

Mahorto, E., Kepramerani, P., \& Novitasari, N. L. G. (2019). Pengaruh kinerja keuangan, inflasi dan tingkat suku bunga terhadap nilai perusahaan. Prosiding Semnas Hasil Penelitian Unmas Denpasar.

Mareta, S., \& Yanti, I. D. (2019). The influence of liquidity, leverage and profitability on company value (empirical study on basic industry and chemical companies listed on Indonesia stock exchange). EPRA IJRM, 5(7).

Margareta, F. (2011). Manajemen keuangan untuk manajer non keuangan. Indonesia: Erlangga.

Mirza, N. Rahat, B., Naqvi, B., \& Rizvi, S. K. A. (2020). Impact of covid-19 on corporate solvency and possible policy responses in the EU. Elsevier Public Health Emergency Collection: PMC7507986.

Mukhsin, M., Lukiana, N., \& Hartono. (2018). Pengaruh likuiditas, solvabilitas, profitabilitas dan nilai pasar terhadap harga saham sektor industri dasar dan kimia di bursa efek Indonesia. Ecobuss, 6(1).

Mulyana, B., Rini, R. (2017). Pengaruh solvabilitas, profitabilitas, ukuran perusahaan dan beta saham terhadap nilai perusahaan serta dampaknya pada return saham perusahaan sub sektor otomotif dan komponennya yang terdaftar di bursa efek Indonesia periode tahun 2010-2016. Jurnal Ilmiah Manajemen $\mathcal{E}$ Bisnis, Indikator, 1(3).

Nugroho, W. C., \& Abdani, F. (2017). Pengaruh Profitabilitas, Dividend Policy, Leverage, Dan Keputusan Investasi Terhadap Nilai Perusahaan Konstruksi Di Bursa Efek Indonesia. El Muhasaba, 8(1).

Peraturan Menteri Kesehatan Republik Indonesia Nomor 59 Tahun 2014. Tentang Standar Tarif Pelayanan Kesehatan Dalam Penyelenggaraan Program Jaminan Kesehatan.

Permana, A. A. N. B. A., \& Rahyuda, H. (2019). Pengaruh profitabilitas, 
solvabilitas, likuiditas dan inflasi terhadap nilai perusahaan. E-Jurnal Manajemen, 8(3).

Permatasari N., \& Suratna. (2019). Pengaruh likuiditas, solvabilitas, profitabilitas terhadap harga saham dengan nilai perusahaan sebagai variable intervening. JABis, 17(1).

Priyanto, S. (2016). Pengaruh Kebijakan Dividen, Profitabilitas Dan Firm Size Terhadap Nilai Perusahaan Pada Perusahaan Yang Tergabung Dalam Jakarta Islamic Indeks Di Bursa Efek Indonesia. Jurnal Akutansi dan Keuangan, 5(1).

Putra, Y. D., \& Wiagustini, N. L. P. (2013) Pengaruh Likuiditas Dan Leverage Terhadap Profitabilitas Dan Nilai Perusahaan Pada Perusahaan Perbankan di BEI. Journal Wawasan Manajemen, 1(2).

Rahmadani, A., (2016). Rumah Sakit Pemerintah Sebagai Organisasi: Struktur, Manajemen, dan Pengembangan Organisasi. Indonesia.

Ramli, R. R. (2020) Kompas. Corona Dinyatakan sebagai Pandemik Penyebab IHSG Anjlok Hari Ini. Diakses pada tanggal 6 Desember 2020 dari https://money. kompas.com/read/2020/03/12/133639626/coronadinyatakan-sebagai-pandemik-penyebab-ihsg-anjlok-hari-ini.

Rehman, M., \& Khidmat, W. (2014). Impact of liquidity \& solvency on profitability chemical sector of Pakistan. Economics Management Innovation, 6(3).

Ruparel, L. (2019) Healthcare Executive. Are Indian Hospital Profitable. Diakses pada tanggal 6 Desember 2020 dari https:/ / www.healthcareexecutive.in/blog/are-indian-hospitalsprofitable\#: :text=Shedding $\% 20$ light $\% 20$ on $\% 20$ the $\%$ 20declining, $\mathrm{a} \%$ 20low\%20of\%206\%20percent.

Sari, I. A. G. D. M., \& Sedana, I. B. P. (2020). Profitability and liquidity on firm value and capital structure as intervening variable. International Research Journal of Management, IT \& Social Sciences, 7(1), 116-127.

Santania, A., \& Jonnardi (2020). Pengaruh profitabilitas, likuiditas, dan solvabilitas terhadap nilai perusahaan. Jurnal Paradigma Akuntansi, 2(2).

Sianipar, M. A., \& Mulyani S. D. (2019). Peran Investment Opportunity Set Sebagai Pemoderasi Pengaruh Kinerja Keuangan, Good corporate Governance Dan Corporate Social Responsibility Terhadap Nilai Perusahaan. Jurnal Akuntasi Trisakti, 4(2).

Soni, P. (2019) Business Insider India. Fortis, Apollo and other top hospitals are spending a lot of what they charge - most of which is going to doctors. Diakses pada tanggal 10 Desember 2020 dari https://www.businessinsider.in/india/news/fortis-apollo-and-otherprivate-hospitals-in-india-spend-most-of-their-revenue-on-doctors / articleshow / 71937301.cms

Suciatiningrum, D. (2020) IDN. Menkes Terawan Minta Rumah Sakit Siaga Hadapi Lonjakan Kasus COVID-19. Diuduh pada tanggal 4 Desember 2020 dari https://www.idntimes.com/news/indonesia/dinisuciatiningrum/menkes-terawan-minta-rumah-sakit-siaga-hadapi-lonjakankasus-covid/1

Sugiyono. (2013). Metode Penelitian Pendidikan Pendekatan Kuantitatif, Kualitatif, 
dan RED. Bandung: Alfabeta.

Syafuddin, D. T. D., Sabrin, Sarita B., \& Sujono (2016). The Effect of Profitability on firm value in manufacturing company at Indonesia stock exchange. The IJES, 5(10), 81-89.

Trisnantoro, L. (2004). Memahami Penggunaan Ilmu Ekonomi dalam Manajemen Rumah Sakit. Gajah Mada University Press.

Trisnantoro, L. (2005). Aspek Strategis Manajemen Rumah Sakit: Antara Misi Sosial dan Tekanan Pasar. Andi Offset.

Trisnantoro, L. (2009). Pelaksanaan Desentralisasi Kesehatan di Indonesia 2000 - 2007 Mengkaji Pengalaman dan Skenario Masa Depan. BPFE Yogyakarta.

Tulsian, M. (2014). Profitability Analysis (A comparative study of SAIL \& TATA Steel). IOSR-JEF, 3 (2), 19-22.

Uttari, I. A. S., \& Yadnya, I P. (2018) Pengaruh Likuiditas Dan Struktur Modal Terhadap Kebijakan Dividen Dan Nilai Perusahaan. E-Jurnal Manajemen Unud.

White, M. C. (2018) NBC News. Hospitals made \$21B on Wall Street last year, but are patients seeing those profits. Diuduh pada tanggal 10 Desember 2020. dari https://www.nbcnews.com/ business/ business-news/hospitalsmade-21b-wall-street-last-year-are-patients- seeing-n845176

Wijaya, R. A. \& Suganda T. R. (2020). Pengaruh Investment Opportunity Set, Kinerja Keuangan, Dan Intangible Asset Terhadap Nilai Perusahaan. d, 17(2).

World Health Organization (2009) Handbook on Monitoring and Evaluation of Human Resources for Health with special applications for low- and middleincome countries. Diuduh pada tanggal 4 desember 2020 dari https://www.who.int/hrh/resources/handbook/en/

Yuniartha, L. (2020) Kontan. Menumpuk, utang klaim jatuh tempo BPJS Kesehatan ke rumah sakit capai Rp 4,4 triliun. Diuduh pada tanggal 4 desember 2020 dari https://keuangan.kontan.co.id/news/ menumpukutang-klaim-jatuh-tempo-bpjs-kesehatan-ke-rumah-sakit-capai-rp-44-triliun. 